\title{
Effect of Municipal Solid Waste Leachate on Soil Enzymes
}

\author{
G.S.J. Shailaja*†, N. Srinivas* and P.V.V. Prasad Rao** \\ *Department of Environmental Science, GITAM Institute of Science, GITAM University, Visakhapatnam-530045, \\ Andhra Pradesh, India \\ **Department of Environmental Science, Andhra University, Visakhapatnam-53000, Andhra Pradesh, India \\ †Corresponding author: G.S.J. Shailaja; sailajaenviron@gmail.com
}

Nat. Env. \& Poll. Tech. Website: www.neptjournal.com

Received: 09-05-2020

Revised: $03-07-2020$

Accepted: 13-07-2020

Key Words:

Municipal solid waste

Leachate

Soil enzymes

Dumpsite

\begin{abstract}
The paper aims to investigate the enzyme activity of soils exposed to Municipal Solid Waste (MSW) leachate. Soil enzymes are useful indicators for soil quality management as they respond to changes that occur in soil quality. To determine the effects of MSW leachate, three sites, i.e. Leachate Exposed Site (LES), Partially Leachate Exposed Site (PES) and Control Soil (CS) were considered located in and around Kapuluppada dumpsite which falls under Visakhapatnam city limits. The LES soil receives more leachate washings due to its proximity to waste heaps compared to PES soil. The third site, i.e. CS is located a little away from the MSW heaps and is free from any contamination. The samples were estimated for enzymes like dehydrogenase, invertase, alkaline phosphatase, protease, amylase and cellulase activity using standard assay methods. The following trend was observed: protease>amylase>invertase>alkaline phosphatase>dehydrogenase>cellulase. Our results indicate that the enzymes showed higher activity with MSW leachate washings due to enhanced soil aeration and soil porosity. However, MSW leachate washings had not shown any significant inhibitive effect on organic carbon content, microbial biomass and enzymatic activities.
\end{abstract}

\section{INTRODUCTION}

Enzymes are known to catalyse many biological transformations occurring in soils which may be intracellular or extracellular (Thien \& Myers 1992, Deng \& Tabatabai 1997, Rao et al. 2000, Fuentes et al. 2006). It is believed that vegetation affects soil enzyme activities as the organic compounds are supplied to soil from plant and animal residues and other dead organisms (Mathur et al. 1980). As enzymes present in soil are of plant, animal and microbial origin, their activities reflect the metabolic status of soils.

Enzymes also participate in the formation and degradation of wastes and contribute to nutrient cycling (Tabatabai 1994, Dick et al. 1994, Taylor et al. 1989, Johansson et al. 2000, Li et al. 2014). The microbes and enzymes present in the soil play an active role in providing fertility to the soil and also involved in the nutrient cycles (biogeochemical cycles) that are essential for the growth of plants. They also act as biological indicators (Chinyere et al. 2013). The enzyme levels in soil vary due to different amounts of organic matter content, composition and activity of living organisms and the biological processes. The role of soil enzymes in the ecosystem will provide an opportunity for biological assessment of soils due to their ease of measurement and response to changes in soil management practices (Dick 1994, Dick 1997, Bandick \& Dick 1999, Joachim et al. 2008).
The activity of enzymes involved in the transformation of nutrients is also a measure of soil microbial population (Crecchio et al. 2004). However, any disturbances in the soil system due to wastes/toxic chemicals may lead to a change in the soil system. Therefore, enzyme activities in the soil are indicators of stress management and warn us about soil degradation (Bergstrom et al. 1998, Margesin et al. 2000, Li et al. 2014). Kandeler et al. (1996) reported that a high concentration of heavy metals affects the growth, morphology and metabolism of microorganisms in soils. Baath (1989), Doelman \& Haanstra (1989), Aoyama \& Nagumo (1996) reported that heavy metals at high concentration reduce soil microbial activities like respiration, ammonification, nitrification and enzyme activities. In addition to the fundamental properties of enzymes in the soil, the data from enzyme assays are used as a guide for soil quality management (Powlson \& Jenkinnson 1981, Garcia et al. 2000), an indirect measure of microbial biomass e.g. dehydrogenase activity (Ladd 1978) and a pointer towards the effects caused by wastes (Tyler 1974, Doelman \& Haanstra 1979).

In the present study, the impact of MSW leachate exposed soil i.e., LES, PES and CS soil were assayed.

\section{MATERIALS AND METHODS}

Study area: The Kapuluppada dumping yard, a 100 acres 
of low lying area with good vegetation has a tropical climate with little temperature variations throughout the year with May being the hottest and January the coldest month. It is covered with hills on two sides and a narrow opening connecting to the city on the other side. The total annual rainfall is around $955 \mathrm{~mm}$. Three sites were considered which includes leachate exposed site (LES), partially leachate exposed site (PES) and control soil (CS). These sites are located in and around the Kapuluppada dumpsite which falls under Visakhapatnam metropolitan region.

The soil is red loamy. Various annual and perennial species, the majority being local, can be observed in this area. The Leachate Exposed Site (LES), Partially Exposed Site (PES) and Control Site (CS) are distinctly located in the study area (Fig 1). The LES is located $100 \mathrm{~m}$ away from the waste heaps; PES is $500 \mathrm{~m}$ away while CS is far away and $500 \mathrm{~m}$ away from PES. LES is close to the waste heaps and the leachate generated from the waste heaps continuously flow over the LES soil. During the rainy season and the advent of cyclonic storms the leachate flow increases on the soil surface, hence accumulated is more. The PES receives fewer leachate washings than the LES since it is far away from the waste heaps. The third CS is nearer to the plane grassland and far away from the municipal solid waste heaps and nearly free from contamination.

Sampling Frequency: A $10 \mathrm{~m} \times 10 \mathrm{~m}$ quadrat was selected from each of the sample sites. Each quadrat was divided into 10 sub-plots, each of $1 \mathrm{~m}^{2}$ area. Soil samples were collected from the subplots with the help of soil corer; tagged and sealed in polythene bags and were brought to the laboratory with necessary precautions. Samples were collected during morning hours on the $10^{\text {th }}$ day of every month from December 2002 to April 2004.

Enzymes in the soil samples were estimated as per the methods specified by Casida et al. (1964), Tabatabai \& Bremner (1969), Eivazi \& Tabatabai (1977), Speir \& Ross (1975) and Cole (1977). All the chemicals and reagents used were of analytical grade and deionized double distilled water (DDW) was used throughout the analysis.

\section{RESULTS AND DISCUSSION}

The activities of various enzymes in LES, PES and CS soils are presented in Figs. 2-7. Enzymes are biological

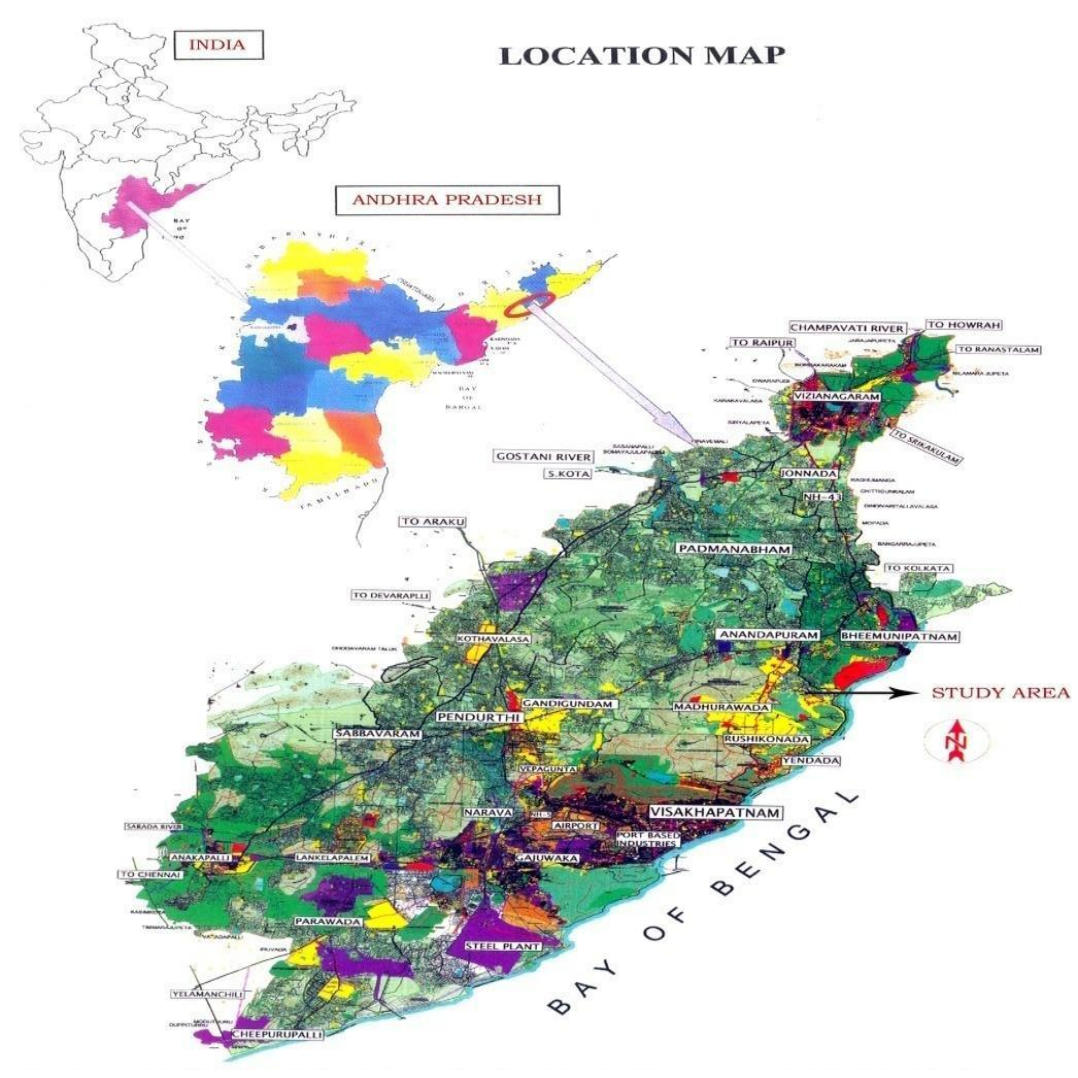

Fig. 1: Visakhapatnam Metropolitan region showing the study area. 
catalysts and are of great agronomic and ecological value. Soil enzymes are assayed since many enzymes immediately respond to change in soil fertility. Therefore, enzymes are used as indicators for soil quality management (Powlson \& Jenkinson 1981, Garcia et al. 2000, Joachim et al. 2008). Since enzymes react to changes in soil management practice more rapidly they may also be useful as indicators of biological changes (Bandick et al. 1999 and Masciandaro et al. 2004). The activities of various enzymes in LES, PES and CS soils are presented in Figs. 2-7. The dehydrogenase activity of LES soil ranged from 0.004 to $0.066 \mathrm{mg} / \mathrm{g} / \mathrm{hr}$, PES 0.005 to 0.045 $\mathrm{mg} / \mathrm{g} / \mathrm{hr}$ and CS 0.002 to $0.043 \mathrm{mg} / \mathrm{g} / \mathrm{hr}$. The results indicate that among the three sites dehydrogenase activity was high in LES. The enzyme dehydrogenase is an indicator of biological activity in soils (Burns 1978). It oxidizes soil organic matter (Doelman \& Haanstra 1979, Kandeler et al. 1996, Glinski \& Stepniewski 1985). In the present study, dehydrogenase activity was reported to be low compared to the other enzymes studied. Among the three study sites, dehydrogenase activity was high in LES soil compared to PES and CS. Rinku et al. (2017) reported that the dehydrogenase activity increased with increasing amounts of uncontaminated sewage sludge in the initial 15 days, but after 30 days it declined. Pitchel \& Hayes (1990) also reported low dehydrogenase activity in soil



Fig. 2: Min, Max and Mean values of dehydrogenase, alkaline phosphatase and protease activity of LES soil.



Fig. 4: Min, Max and Mean values of dehydrogenase, alkaline phosphatase and protease of PES soil. polluted with fly ash. Several authors (Doelman \& Haanstra 1979, Rossel \& Tarradellas 1991) have reported the inhibition of dehydrogenase by metal pollution. Marzadori et al. (1996) and Chander et al. (1991) have also reported that the activity of dehydrogenase was inhibited particularly by the presence of $\mathrm{Pb}$ and $\mathrm{Cu}$ in municipal sewage sludge. However, in our study dehydrogenase activity has not shown any significant inhibition in LES and PES soils over CS soil. The result indicates that the dehydrogenase enzyme in the soil indicates the potential of the soil to support biochemical processes essential for maintaining soil fertility (Joachim et al. 2008). Joachim et al. (2008) also suggested that dehydrogenase could be a good indicator of microbial activities in soils in semiarid areas.

Alkaline phosphatase activity of LES and PES site soils ranged from 0.001 to 0.084 and 0.012 to $0.083 \mathrm{mg} / \mathrm{g} / \mathrm{hr}$ respectively. The enzyme phosphatase plays a vital role in the phosphorus cycle, by allowing orthophosphate to be released from organic and inorganic compounds and thus increasing the bioavailability of phosphorus. Several researchers (Thien \& Myers 1992, Deng \& Tabatabai 1997, Rao et al. 2000) have also studied the role of phosphatase in the phosphorus cycle and its bioavailability in soil. Phosphatase is commonly used to examine the toxicity of metals (Doelman \& Haanstra



Fig. 3: Min, Max and Mean values of amylase, invertase and cellulase activity of LES soil.



Fig. 5: Min, Max and Mean values of amylase, invertase and cellulase activity of PES soil. 


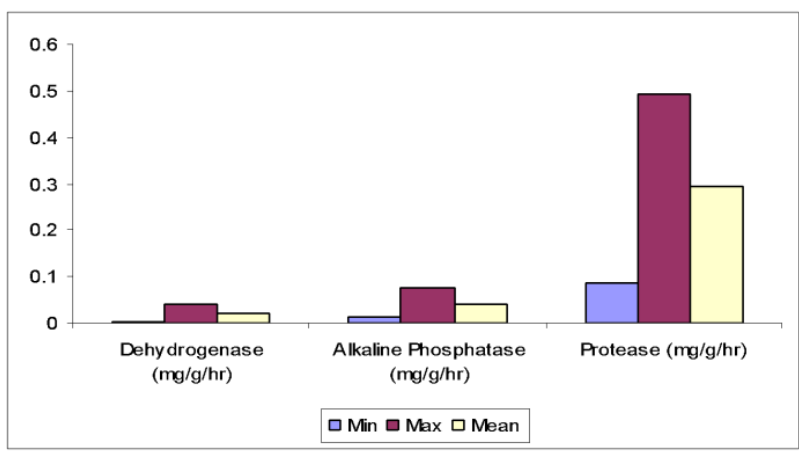

Fig. 6: Min, Max and Mean values of dehydrogenase, alkaline phosphatase and protease activity of CS.

1989) or organic pollutants such as pesticides. The variations in phosphatase activity may be due to an increase in soil moisture content because phosphatase activity is observed to be higher in saturated soil than in dry soil (Gavrilova \& Shimko 1969, Daraseliya et al. 1975). The present study reveals that the alkaline phosphatase activity was not inhibited by leachates despite their heavy metal content (Tam 1998). Chinyere et al. (2013) while studying the soil enzyme activity of Njoku solid waste dump site Owerri municipal, Nigeria, reported that the alkaline phosphatase activity was not affected by waste dumping.

Proteases play an important role in $\mathrm{N}$ mineralization (Ladd \& Jackson 1982). Urease and protease hydrolyse nitrogen compounds to ammonium using urea and low molecular weight protein substrates respectively (GarciaGill et al. 2000). Protease activity occurs partly in the soil as a humocarbohydrate complex (Mayaudon et al. 1975, Bastistic et al. 1980), from arable soil (Ladd 1972, Mayaudon et al. 1975, Hayano et al. 1987), from solid municipal waste compost (Rad et al. 1995) and forest or permanent grassland soils (Nannipieri et al. 1980, 1982, 1985). In the present study protease activity ranged from 0.177 to $0.580 \mathrm{mg} / \mathrm{g} / \mathrm{hr}$, 0.091 to $0.563 \mathrm{mg} / \mathrm{g} / \mathrm{hr}$ at LES and PES soils respectively. Among the three study sites, the LES soil showed increasing protease activity due to more quantity of leachate washings. The present observations along with the earlier observations (Ross 1977, Mishra et al. 1979, 1988, Mohanty \& Padhan 1992) suggest that variation in soil protease activity might be due to the changes in soil physicochemical properties and microbial biomass.

The amylase activity at LES and PES sites ranged from $0.091-0.550 \mathrm{mg} / \mathrm{g} / \mathrm{hr}, 0.056$ to $0.520 \mathrm{mg} / \mathrm{g} / \mathrm{hr}$ respectively. Amylase activity was reported to be high at LES soil. Variations in amylase activity were observed among the LES and PES soils due to differential leachate washings. Galstyan (1965), Ross \& Roberts (1970), Cortez et al. (1972), Mishra et al. (1984) and Mishra \& Pradhan (1987) observed seasonal



Fig. 7: Min, Max and Mean values of amylase, invertase and cellulase activity of CS.

variations in soil amylase activity.

The invertase activity of LES soil ranged from 0.01 to $0.71 \mathrm{mg} / \mathrm{g} / \mathrm{hr}$ and PES soil ranged from 0.01 to $0.36 \mathrm{mg} / \mathrm{g} / \mathrm{hr}$. The findings indicate that invertase activity varied seasonally (Raguotis 1967, Cortez et al. 1972, Mishra et al. 1984, Mishra \& Pradhan 1987). In the present study, invertase activity showed a significant correlation with organic carbon (Vekhrer \& Shamshieva 1968, Kiss et al. 1971, Mishra et al. 1979).

Cellulase activity of LES and PES soils ranged from 0.007 to $0.056 \mathrm{mg} / \mathrm{g} / \mathrm{hr}, 0.009$ to $0.060 \mathrm{mg} / \mathrm{g} / \mathrm{hr}$ respectively. The cellulase activity was reported to be high at LES and PES soil over control. However, the LES and PES site soils showed significant variations. Mishra et al. (1984) observed seasonal variations in cellulase activity in some tropical grassland soils and related the variation in cellulase activity to the variation in cellulase secreting microorganisms. Hence, the seasonal variation in cellulase activity may be due to variation in microbial populations, vegetation and physicochemical factors operating in a particular ecosystem.

Correlation among enzymatic activities in the field: The majority of the enzymes were found to be involved in microbial oxidoreductase metabolism. The activity of such enzymes depends on the metabolic state of the soil biota. Dehydrogenase and amylase were found to be significantly correlated with soil microbial biomass in both the LES and PES soils. This indicates that dehydrogenase and amylase activity could be a good indicator of soil microbial activity in MSW exposed soils (Garcia et al. 1994b). A significant increase in dehydrogenase and amylase activity occurred in LES and PES sites than control soil. This is due to the presence of high amounts of humidified organic matter in MSW which is more resistant to microbial mineralization (Garcia-Gill et al. 2000). Tam (1998) reported that dehydrogenase activity in soils receiving wastewater was similar to control throughout the experiment suggesting that the activity was not affected by the addition of wastewater containing heavy metals. 
Protease activity was higher in both LES and PES sites. This may be due to the presence of a high concentration of metabolites such as $\mathrm{NH}_{4}$ (Konig et al. 1966) as a consequence of the mineralization process in soil. Changes in soil phosphatase activity, which play an essential role in the mineralization of organic phosphorus were also observed in both LES and PES sites and exhibited an increase in the enzyme activity. Alkaline phosphatase was significantly correlated with protease $(\mathrm{P}<0.005)$. Generally, this enzyme is activated when there is low phosphorus availability in soils.

\section{CONCLUSION}

All the enzymes have shown a higher activity with MSW leachate washings. This result may be explained by the improved soil aeration and soil porosity. The strong bonding of enzymes to soil colloids also may protect the enzyme from denaturation. The leachate had not shown any significant effect on the organic carbon content, microbial biomass and enzymatic activities. The reason for the harmfulness of both LES and PES is the leachates that increase in the soil $\mathrm{pH}$ which inhibits metal toxicity and converts ammoniacal nitrogen into non-ionized ammonia. Overall, our results have shown that the MSW and the leachate washings have not shown any significant inhibitive effect on soil biological and biochemical properties.

\section{ACKNOWLEDGEMENT}

The authors are thankful to University Grants Commission (UGC), New Delhi, India, for providing financial assistance to carry out the work and GITAM University, Visakhapatnam, AP, India, for extending the necessary facilities.

\section{REFERENCES}

Aoyama, M. and Nagumo, T. 1996. Factors affecting microbial biomass and dehydrogenase activity in apple orchard soils with heavy metal accumulation. Soil Science and Plant Nutrition, 42: 821-831.

Baath, E. 1989. Effects of heavy metals in soil on microbial processes and population, a review. Water, Air and Soil Pollution, 47: 335-379.

Bandick, A.K. and Dick, R.P. 1999. Field management effects on soil enzyme activities. Soil Biol. Biochem., 31: 1471-1479.

Bastistic, L., Sarkar, J. M. and Mayaudon, J. 1980. Extraction, purification and properties of soil hydrolases. Soil Biol. Biochem., 12: 59-63.

Bergstrom, D.W., Monreal C.M. and King D.J. 1998. Sensitivity of soil enzyme activities to conservation practices. Soil Science Society of America Journal, 62: 1286-1295.

Burns, R.G. 1978. Enzyme activity in soil: Some theoretical and practical considerations. In: Soil Enzymes (Bums R.G., Ed.). Academic Press, London, pp. 295-340.

Casida, L.E., Klein, D.A. and Santro, T. 1964. Soil dehydrogenase activity. Soil. Sci., 98: 371-376.

Chander, K. and Brookes, P.C. 1991. Is the dehydrogenase assay invalid as a method to estimate microbial activity in copper-contaminated soils? Soil Biology \& Biochemistry, 23: 909-915.
Chinyere, G.C., Obisike, E.S., Ugbogu, A.E. and Osuocha, K.U. 2013. Studies on municipal solid wastes dumping on soil anions, cations and selected enzymes activities at Njoku sawmill waste dumpsite, Owerri Municipal, Imo State, Nigeria. Ethiopian Journal of Environmental Studies and Management, 6: 774-783.

Cole, M.A. 1977. Lead inhibition of enzyme synthesis in soil. Applied and Environmental Microbiology, 33: 262-268.

Coleman, D.C. 1976. A review of root production processes and their influence on the soil biota of terrestrial ecosystems. In: The Role of Terrestrial and Aquatic Organisms in Decomposition Processes. (Ed.) Anderson J.M. \& Macfayden, A. Backwell Scientific Publication. Oxford, pp. 417-434.

Cortez, J., Lossaint, P. and Billes, G. 1972. Soil biological activity in Mediterranean ecosystem III. Enzymatic activity. Rev. Ecol. Biol. Sol., 9: 1-19.

Crecchio, C., Curci, M., Pizzigallo, M., Riccuti, P. and Ruggeiro, P. 2004. Effects of municipal solid waste compost amendments on soil enzyme activities and bacterial genetic diversity. Soil Biol. Biochem., 36: 1595-1605.

Daraseliya, N. A., Kalatozova, G.B. and Dzadzamiya, T.D. 1975. Microbiological and enzymatic activity of podzolic-gley and Kraznozem soils with various moisture contents. Subtrop. Kult, 1: 103-105.

Deng, S.P. and Tabatabai, M. A. 1997. Effect of tillage and residue management on enzyme activities in soils: III. Phosphatases and arylsulfatase. Biol. Fertil. Soils., 24: 141-146.

Dick, R. P. 1994. Soil enzyme activities as indicators of soil quality. In: Doran, J.V., Coleman, D.C., Bezdicek, D.F., Stewart, B.A., (Eds.). Defining Soil Quality for sustainable Environment, Soil Science Society of America, American Society of Agriculture, Madison, pp. 107-124.

Dick, R. P., Sandor, J.A. and Eash, N. S. 1994. Soil enzyme activities after 1500 years of terrace agriculture in the Colca Valley, Peru. Agric. Ecosyst. Environ., 50: 123-131.

Dick, R.P. 1997. Soil Enzyme activities as integrative indicators of soil health. In: Pankhurst, C.E., Doube, B.M., Gupta, V.V.S.R., (Eds.). Biological Indicators of Soil Health, CAB International, Wellingford, pp. 121-156.

Doelman, P. and Haanstra, L. 1979. Effect of lead on soil respiration and dehydrogenase activity. Soil Biol. Biochem., 11: 475-479.

Doelman, P. and Haanstra, L. 1989. Short and long term effects of heavy metals on phosphatase activities in soils: an ecological dose response model approach. Biol. and Fertil. of Soils, 8: 235-241.

Eivazi, F. and Tabatabai, M. A. 1977. Phosphatases in soils. Soil Biol. Biochem., 9: 167-172.

Fuentes, B., Bolan, N., Naidu, R. and Mora, M.D.L.L. 2006. Phosphorus in organic waste-soil systems. J. Soil Sc. Plant Nutr., 6(2): 64-83.

Galstyan, A. Sh. 1965. The dynamics of Ferman processes of soils. DakladyAkad. Army. SSR, 40: 39-42.

Garcia, C., Hernandez, T., Costa, F. and Ceccanti, B. 1994b. Biochemical parameters in soil regenerated by addition of organic wastes. Waste Management and Research, 12: 457-466.

Garcia-Gill, Plaza, J.C., Soler-rovira, C. and Polo, P. 2000. Longterm effects of municipal solid waste compost application on soil enzyme activities and microbial biomass. Soil Biol. Biochem., 32: 1907-1913.

Gavrilova, A. N. and Shimko. 1969. Organophosphate level and phosphatase activity in some soil of the Beloreosslen. SSSR. Vesti. Akad. Navuk. BSSR. Ser. Biyal. Navuk., 6: 35-41, (Chem. Abstr. 72.99560).

Glinski, J. and Stepniewski, W. 1985. Soil Aeration and its Role for Plants. CRC Press, Boca Raton, Florida.

Hayano, K., Takeuchi, M. and Ichishima, M. 1987. Characterization of a metalloproteinase component extracted from soil. Biol. Fert. Soils., 4: 179-183. 
Joachim, H.J.R., Makoi, Patrick and A. Ndakidemi 2008. Selected soil enzymes: Examples of their potential roles in the ecosystem. Af. Jr. of Biotech., 7(3): 181-191.

Johansson, E., Krantz-Rülcker, C., Zhang, B.X. and Öberg, G. 2000. Chlorination and biodegradation of lignin. Soil Biology and Biochemistry, 32: 1029-1032.

Kandeler, E. 1996. Nitrate. In: Schinner. F., Ohlinger, R., Kandeler, E., Margesin R (eds). Methods in Soil Biology. Springer, Berlin Heidelberg, New York, pp. 408-410.

Kandeler, E., Kampichler, C. and Horak, O. 1996. Influence of heavy metals on the functional diversity of soil microbial communities. Biol. Fert. Soils, 23: 299-306.

Kiss, S., Dragan-Bilarda, M. and Radulescu, D. 1971. Biological significance of enzymes accumulated in soil. Contrib. Bot. Cluj., 377-397.

Kiss, S., Dragan-Bilarda, M. and Radulescu, D. 1978. Soil polysaccharides: Activity and agricultural importance. Chapter 4. In: Burns, R.G. (ed.) Soil Enzymes. Academic Press, London.

Konig, C., Kaltwasser, H. and Schiegel, H.G. 1966. The formation of urease after use of other nitrogen sources on Hidrogenumonas. Archives of Microbiology, 53: 231-241.

Ladd, J.N. 1972. Properties of proteolytic enzymes extracted from soil. Soil Biol. Biochem., 4: 227-237.

Ladd, J.N. 1978. Origin and range of enzymes in soil. In: Burns, R.G. (Ed.). Soil Enzymes, Academic Press, London, pp. 51-56.

Ladd, J.N. and Jackson, R.B. 1982. Nitrogen in agricultural soils. Am. Scc. Agron., Wl. pp. 173-228.

Ladd, J.N. and Paul, E.A. 1973. Changes in enzymatic activity and distribution of acid-soluble amino acid-nitrogen in soil during nitrogen immobilization and mineralization. Soil Biol. Biochem., 5: 825-840.

Li, Q., Liang, J.H., He,Y.Y., Hu, Q.J. and Yu, S. 2014. Effect of land use on soil enzyme activities at karst area in Nanchuan, Chongqing, Southwest China. Plant Soil Environ., 16(1): 15-20.

Margesin, R., Zimmerbauer, A. and Schinner, F. 2000. Monitoring of bioremediation by soil biological activities. Chemosphere, 40: 339-346.

Marzadori, C., Ciavatta, C., Montecchio, D. and Gessa, C. 1996. Effects of lead pollution on different soil enzyme activities. Biology and Fertility of Soils, 22: 53-58.

Masciandaro, G., Ceccanti, B., Benedicto, S., Lee, H.C. and Cook, F. 2004. Enzyme activity and $\mathrm{C}$ and $\mathrm{N}$ pools in soil following application of mulches. Can. J. Soil Sci., 84: 19-30.

Mathur, S.P., Macdougall, J.I. and McGrath, M. 1980. Levels of activities of some carbohydrases, protease, lipase and phosphatase in organic soils of differing copper content. Soil Sci., 129: 376-385.

Mayaudon, J, Bastistic, L. and Sarkar, J. M. 1975. Proprietes des activites proteolitiquesextraites des sols frais. Soil Biol. Biochem., 7: 281-286.

Mishra, P.C. and Pradhan, S.C. 1987. Seasonal variation in amylase, invertase, cellulase activity and carbon dioxide evolution in tropical protected grassland of Orissa, India, sprayed with carbaryl insecticide. Environment Pollution, 43: 291-300.

Mishra, P.C., Mohanty, R.K. and Dash, M.C. 1979. Enzyme activity in subtropical surface soils under pasture. Ind. J. Agric. Chem., 12(1): 19-24.

Mishra, P.C., Pradhan, S.C., Mishra, P.K. and Sahoo, S. 1988. Protease activity in a grassland soil treated with carboxyl insecticide. Pollution Research, 7(1-2): 13-15.

Mishra, P.C., Satpathy, G.R., Patnaik, H.K. and Dash, M.C. 1984. Effect of Malathion treatment on soil metabolism of a tropical grassland ecosystem of Orissa, India. Proc. Nat. Seminar on Organic Waste Utilization and Vermicomposting. School of Life S. Sambalpur Univ. India, Dec 5-8.

Mohanty, R.K. and Padhan, S. 1992. Comparative studies on soil enzyme activities under two types of crops and adjacent grassland vegetation. Tropical Ecology, 33 (2): 205-213.
Nannipieri, P., Ceccanti, B., Bianchi, D. and Bonmati, M. 1985. Fractionation of hydrolase-humus complexes by gel chromatography. Biol. Fert. Soils, 1: 25-29.

Nannipieri, P., Ceccanti, B., Cervelli, S. and Matarese, E. 1980. Extraction of phosphatase, urease, proteases, organic carbon and nitrogen from soil. SSSAJ, 44: 1011-1016.

Nannipieri, P., Ceccanti, B., Conti, C. and Bianchi, D. 1982. Hydrolases extracted from soil: their properties and activities. Soil Biol. Biochem., 14: 257-263.

Pascual, J.A., Garcia, C. and Hernandez, T. 1999. Lasting microbiological and biochemical effects of the addition of municipal solid waste to an arid soil. Biol. Fertil. Soils, 30: 1-6.

Pitchel, J.R. and Haynes, J. M. 1990. Influence of fly ash on soil microbial activity and populations. J. Environ. Qual., 19: 593-597.

Powlson, D.S. and Jenkison, D.S. 1981. A comparison of the organic matter, biomass, adenosine triphosphate and mineralise nitrogen content of ploughed and direct-drilled soils. J. Agric. Sci. Cambridge., 97: 713-721.

Rad, J.C., Navarro-Gonzalez, M. and Gonzalez-Carcedo, S. 1995. Characterization of proteases extracted from a compost of municipal solid wastes. Geomicrobiol. J., 13: 45-56.

Raguotis, A.D. 1967. Biological activity of sod-podzolic forest soils of the Lithuanian SSR. Pochvovedenie., 6: 51-56.

Rao, M.A., Violante, A. and Gianfreda, L. 2000. Interaction of acid phosphatase with clays, organic molecules and organo-mineral complexes: Kinetic and stability. Soil Biol. Biochem., 32: 1007-1014.

Rinku, D., Suman, C., Tanvi, B. and Sneh, G. 2017. Impact of Long term application of municipal solid waste on physicochemical and microbial parameters and heavy metal distribution in soils in accordance to its agricultural uses. International Journal of Agricultural and Biosystems Engineering, 11(6): 399-407.

Ross, D.J. 1977. Protease activities and its relationship to nitrogen mineralization in some soils under pasture and tussock grassland. N.S.J. Sci., 20: 179-185.

Ross, D.J. and Roberts, H.S. 1970. Enzyme activities and oxygen uptakes of soils under pasture in temperature and rainfall sequences. J. Soil Sci., 21: 368-381.

Ross, D.J. and Speir, T.W. 1979. Biochemical activities of organic soils from sub-antarctictusock grassland on CampbellIsland. Enzyme activities N.Z.J. Sci., 22: 173-182.

Rossel, D. and Tarradellas, J. 1991. Dehydrogenase activity of soil microflora, significance in ecotoxicological tests. Environmental Toxicology and Water Quality, 6: 17-33.

Speir., T.W. and Ross, D.J. 1975. Effects of storage on the activities of Protease, urease, phosphatase and Sulphatase in three soils under pasture. Newzealand Journal of Science, 18: 213-237.

Tabatabai, M. A. 1994. Soil enzymes. In: Weaver R, W., Angle J.S., Bottomley, P.S., (Eds.). Methods of Soil Analysis, Part 2. Microbiological and Biochemical Properties. SSSA Book Series No.5. Soil Sci. Soc. Am. Madison, Wis., pp. 775-833.

Tabatabai, M. A. and Bermner, J.M. 1969. Use of p-nitrophenyl phosphate for assay of soil phosphatase activity. Soil. Biol. Biochem., 1: 301-307.

Tam, N.F.Y. 1998. Effects of wastewater discharge on microbial populations and enzyme activities in mangrove soils. Env. Pollution., 102: 233-242.

Taylor, B.R., Parkinson, D. and Parsons, W.F.J. 1989. Nitrogen and lignin content as predictors of litter decay rates: A microcosm test. Ecology, 70: $97-104$

Thien, S.J. and Myers, R. 1992. Determination of bioavailable phosphorus in soil. Soil. Sci. Soc. Am. J., 56: 814-818.

Tyler, G. 1974. Heavy metal pollution and soil enzymatic activity. Pl. Soil, 41: 303-311.

Vekhrer, E.G.K.T. and Shamshieva, 1968. Activity of some enzymes in soils of central Tein Shan. Pochvovedenie, 3: 94-100. 